\title{
THE STATE OF NATURE CONSERVATION IN SWAZILAND: PAST AND PRESENT
}

\author{
T E REILLY and ELIZABETH A REILLY
}

\author{
Swaziland National Trust Commission \\ Mlilwane Wildlife Sanctuary \\ PO Box 33 \\ Mbabane \\ Swaziland
}

\section{Introduction}

Swaziland is a Kingdom under the stable leadership of His Majesty, King Sobhuza II, Ngwenyama of Swaziland. His Majesty is the longest reigning monarch in the world, and is an active protagonist of nature. He has championed its cause in Swaziland through very difficult times. His Majesty is Patron in Chief of both wildlife sanctuaries in the Kingdom, and is personally involved with their development. The success that has been achieved in nature conservation in Swaziland to date, would not have been possible without His Majesty's active support.

Everything relevant to nature conservation in Swaziland must be viewed against this Kingdom's size and background. Swaziland is only $17162 \mathrm{~km}^{2}$ in extent - an area considerably less in size than the Kruger National Park, and some of the other larger national parks and game reserves in Africa. Being a fertile, rich and versatile country, and reputedly having one of the highest birth rates in the world, human encroachment on wild areas and industrial development are changing very rapidly the face of the land. Because of this country's small size, the impact of these developments on the natural environment is much more meaningful in Swaziland today than it is in most of the larger countries in Africa.

Tradition in Swaziland is closely interwoven with the country's wildlife. For instance, our King is respectfully called the Ngwenyama, or lion, and our Queen Mother is the Ndlovukati, or cow elephant. Sadly, neither of these wildlife species survives in our country.

Technological development has also found its place in Swaziland. It promises enormous material benefit to the country as a whole. Technological advances are competing very seriously with traditional stability. Unless timely cognisance is taken of the changing situation, it could get completely out of hand, and may even overcome the last vestige of traditional culture in the land. Unless individual and national 
pride in Swazi tradition is actively encouraged and permitted to continue to manifest itself, it will inevitably disappear. These traditions have evolved over many thousands of years, and could disappear in less than a lifetime. Unless moderation prevails, the price for total acceptance of foreign values, which the Swazi is increasingly being persuaded to adopt, must inevitably be loss of identity.

\section{Pre-historical findings}

Africa is often referred to as the cradle of Man. Swaziland itself is well endowed with palaeontological findings. In fact the earliest known record of our species, Homo sapiens, comes from Swaziland. A recent discovery by Beaumont shows Homo sapiens to have existed in the Lubombo mountains at least 50000 years ago, this being the present limit of C14 dating. Indeed, surrounding evidence suggests, by Beaumont's estimation, that this date may possibly even be pushed back to something of the order of 90000 years. This would more than double the previous proven dating of our species.

Of interest also is another discovery by Beaumont in Swaziland, this being the most ancient mining activity of Homo sapiens recorded to date. Beaumont researched the ancient pigment mine at Ngwenya mountain in western Swaziland, and found the mining activity of Homo sapiens to date back 42000 years.

Beaumont has also found in a cave in Swaziland's Lubombo mountains the remains of many species of animals now either totally or locally extinct. These remains have been identified by Klein, and from his faunal lists it is interesting to see the presence of Antidorcas bondii, a lowveld springbok, and of Equus capensis, giant equid, both of which apparently became extinct about 38000 years ago. Klein has also identified what he thinks to be the remains of the now extinct Damaliscus niro, a type of hartebeest. Of $A$. bondii, Klein remarks on the "commonness" of this animal as being ". . . curious, considering that it apparently did not survive much beyond the pre-early Late Stone Age. In those levels where it occurs (in the upper parts of the profile) it tends to be the most common bovid." This clearly suggests that the human dwellers of the time were either very successful predators or scavengers of this species. This in turn poses the question whether primitive man was a contributing factor in the extermination of species. The answer probably lies in something more complex, perhaps the change of habitat (possibly even being induced by Man's use of fire), or climate, or both. This is suggested by the dominance of certain species from different levels in the cave, these different levels representing different periods. Klein notes the dominance of buffalo and bushpig remains at certain levels, and zebra and warthog at others, suggesting a periodical difference in faunal composition and hence a periodical difference in vegetation composition.

A very interesting contradiction arises out of the current absence of 
dassies from the Swaziland Lumbombos. Though available habitat appears to be suitable, the presence of both Procavia capensis and Dendrohyrax arboreus has not been confirmed. Tello of Mocambique has not recorded them on the eastern Lubombo either. Yet in Klein's analysis of faunal remains from a certain cave in the southern Lubombos, these creatures feature prominently. Why did they disappear? Was it disease? Was it climate? It could hardly have been predation. One hundred and thirty km north in the Mlaula cave in Swaziland's northern Lubombos, Klein's analysis of faunal remains revealed a total absence of dassie evidence. Yet we are told that they do occur in the Kruger National Park Lubombos.

This brief look into the distant past does provide a broader base for the subject of nature conservation in Swaziland today.

\section{The advance of civilization}

More recently, but preceding the Bantu migrations from the north, a small inconspicuous people inhabited the country. These people were the bushmen. Like early Man, they apparently lived in perfect balance with nature, hunting and gathering and in no way destroying or threatening the environment on which they depended. We see today evidence of these people all over Swaziland, though regretfully we have done little to protect adequately from vandalism the rock art which we inherited from them. Across our western border on the Transvaal highveld, two individual male bushmen still survive in the Lake Chrissie area. When they pass on, the entire eastern bushman population will have vanished.

More recently still, with the invasion of the south by northern Bantu clans, the landscape began being modified. These people brought with them their flocks of domestic animals and a capacity for agriculture. Shifting cultivation modified ever increasingly the face of the land, and slowly at first, the impact of Man on the environment became lasting. But still Man existed in reasonable harmony with his environment, natural mortality limiting his numbers. During all these times the natural landscape remained relatively intact. And by all accounts it supported wildlife in numbers and variety that no man can ever hope to see again.

Then came Man's invasion from Europe. Thenceforth all was destined to rapid change. Roads were constructed and access to remote places made easier. Communications generally were improved and with these developments came the exposure of Africa's wildlife to technological Man with his gun and his bulldozer and his ever developing skills. His assault on the land was totally successful. To crown this success it was all accompanied by his ever improving attainments in medicine. Mortality was reduced - longevity increased - and the human population blossomed and compounded. 
quote from the Times of Swaziland of 1931-11-26, also substantiates the death of wildlife after the rinderpest:

"Previous to 1897 , vultures were so plentiful in the country that a hunter, having shot a buck, had to hide it if it were left for a few minutes without human supervision. Then the rinderpest came. The country was decimated of cattle and most of the large game died out. The vultures had an orgie. But with a cattleless and gameless country the vultures' food supply ceased. They too died in hundreds of starvation, and for years a vulture was not seen."

\section{Recovery and exploitation of wildlife}

By all accounts the wild populations that remained recovered rapidly after the rinderpest, and Swaziland became a favourite hunting ground for people once more. The Times of Swaziland of 1906 - only 10 years after the rinderpest - mentions wagon loads of biltong being exported which, as the paper put it, "... would feed the whole of the eastern Transvaal for 12 months."

Here too, we have the first of many records of Swaziland's wild heritage being exploited by foreigners, and also of the Colonial Government's apathy towards its protection. The Times of Swaziland of 1906 mentioned that:

"Men who have been preserving a few head of game, left after rinderpest, saw licenced strangers destroy them wholesale. Men came in from the Transvaal who had no property in Swaziland and took out a $£ 1$ licence for 14 days and then shot wagon loads of biltong which they took up to the Transvaal and traded on."

Repeated reference is made to the resentment and dissatisfaction of land owners about the Colonial authorities ignoring their pleas for protection against the wholesale destruction of game on their land.

If this is how some people with vested interests in Swaziland felt, it is not difficult to imagine just how much more strongly the Swazis themselves must have felt, seeing their heritage and this vast protein resource being appropriated. It must be remembered that the Swazis, and their ancestors before them, had relied on this protein since their occupation of the country centuries before. Though it is little realised, the appropriation of this protein resource must have been one of the very first steps at imposing the dependence of the local people on foreign values. An historical analogy to this was the incidence in which the Americans, in a calculated campaign, aimed their blow at the great herds of bison, and in wiping out 150 million of these beasts, effectively exposed the North American Indian to starvation. Kitchener resorted to the same ruthless tactics in the South African war, when he burned the boers' farms and eliminated their food supply on the vast South African 
veld. By declaring war on Swaziland's wildlife, the British, perhaps unwittingly but very effectively, imposed upon the Swazi a greater dependence upon their foreign system. This was not intentional as it had been in the two cases mentioned above, but the end result was exactly the same.

\section{Swaziland's first game reserves}

In spite of the Government's apparent indifference to the wholesale slaughter of Swaziland's wildlife, there is on record the proclamation of a game reserve on the Vermaak concession as far back as 1905. The following is a quote from B Nicholson, Asst Commissioner, Hlatikule, Swaziland, as it appeared in the Colonial Report of 1907-8:

"A Game Reserve was established in this district in May 1905, and comprises practically the whole of the bushveld in this part. In the reserve there are a small number of sassaby, water-buck, wildebeest, a number of kudu, and large numbers of impala, rooirhebuck, bush-buck, duiker, red duiker, stein-buck, and reit-buck are fairly plentiful. The result of the recent tax of $£ 5$ per head imposed in the Transvaal on greyhounds and dogs of similar breed is that a large number of Europeans and natives have sent their dogs into this Territory for sale, and I am afraid that game will suffer accordingly. Considerable damage is caused in the reserve by wild dogs, and occasionally it is visited by a few lions."

This reserve must have covered approximately $20 \%$ of Swaziland, though later it was reduced considerably in size.

A 1914 map shows three large areas, comprising approximately $12 \%$ of the country, as being proclaimed game reserve. These were in effect merely book entries and related to very remote fever-stricken areas in the Swaziland lowveld, where living conditions made these areas unattractive for anything other than game reserves. Two of these reserves were part of the much reduced formerly proclaimed game reserve of 1905 in the Hlatikulu district. After the First World War, these three protected areas were deproclaimed and cut up as farms, and made available for settlement on very easy terms to some of the returned soldiers and others, in an effort to encourage settlement of the south.

\section{Wildebeest "plague" - and mass extermination of game}

The blue wildebeest scourge, so called, of the 1930's is still often spoken about. This in fact must truly have been one of the wildlife wonders of southern Africa at the time, but it was not seen this way by the early settlers. Indeed it provoked tremendous retaliation in which even machine guns and poisons were used to combat it. The so called plague accompanied the final years of a long drought and, it is alleged, brought 
disaster to the farmers and ranchers of central and eastern Swaziland. In their countless thousands, the wildebeest invaded Swaziland from the Komati flats to the north. They demolished fences, consumed the grazing, spread snotsiekte (malignant nasal catarrh) and it is claimed, all but put every stock farmer out of business. Many contradictions arise from the chain of events which followed, and it is understandable that personalities and officials alike today try either to conceal or to dissociate themselves from the carnage which ensued.

Official response to the so called wildebeest plague was perhaps understandable for the times, though extreme. Wildebeest were removed from the game schedule, and were thenceforth hunted ruthlessly by fair means or foul - mainly foul. There are many stories of them being run down in vehicles manned with machine guns. They were hunted on foot and on horseback. It is said that water was even baited with cyanide and other poisons. It is unlikely that many species other than the quelea or locust have been persecuted so relentlessly and with such purpose in Africa before. It went on record that one party with two Vickers machine guns mounted on the back of a pick-up fired two full belts into a vast herd until they had spent their ammunition. Only two animals lay dead when the dust had cleared. Two animals for 600 rounds. The police were officially assigned the duty of machine gunning the herds, and their gunner is said on one occasion to have felled eight animals with a f $\mathrm{ll}$ belt of ammunition (300 rounds).

Other stories pertain to hunters who, having collected more game meat than they could handle, went on to gather wagon loads of wildebeest tails, abandoning a veld full of carcasses to the scavengers. Wildebeest tails could be readily sold at the time for $1 / 6 \mathrm{~d}$ a piece, which was considered by many to be big money and a lucrative activity.

In 1933 the Colonial Government seriously considered a meat powder-meal scheme as a "solution to the wildebeest problem", but for some reason it never got off the ground.

This hostility was not confined to wildebeest, as the following extract shows from the Times of Swaziland of 2nd February, 1933:

"Two buffalo have appeared on Raches Limited. Here is a real call for destruction." This was followed by an article on 23rd February of the same year:

"Mr A M Miller called attention to the presence of buffalo in northern Swaziland, and urged that strong representations be made to the Administration to secure their destruction."

The Times of Swaziland and the Advisory Council minutes of the 1930's were full of talk about the wildebeest - the "filthy detestible disgusting injurious vermin." And through it all one lone voice spoke up for the wild animals. That voice belonged to the late David Forbes, and we 
quote from one of his many appeals to the press at the time, appearing in the Times of Swaziland of 31st August, 1933:

"Some of the farmers on the White Mbuluzi river, with the consent of the Administration, are putting up troughs of poisoned water to kill the wildebeest to save themselves from the small pecuniary loss that will be caused by these animals. You, sir, in your paper have always advocated the destruction of the wildebeeste, but I can hardly believe that you can approve of such a crude and cruel way of accomplishing that end. It is most inhuman to lay a bait for poor innocent animals suffering from the pangs of thirst. God gave man intelligence, but not for the purpose of making use of it in that way. The first victims of these poison traps will be a small herd of 12 Roan antelopes which are now the rarest game animals in South Africa that feed nearest the poisoned troughs. Kudu, impala, a small number of rooi-rhebuck on Skupe hill, and all the other small game will be killed. Thousands of beautiful and useful birds will be killed by poison.

Is there no truly British sporting instinct in Swaziland to protest against this intentional act of cruelty, even if it has the sanction of the Administration. Look at the opposite picture and see how in the Union man are uniting with each other to save these innocent animals from thirst, and are willing to give treasure to save them from destruction, and compare it with the lack of a true sporting spirit in Swaziland."

Forbes, however, was hopelessly outshouted and stood the very real risk of legislation being passed against him, making him, as a landowner of a good deal of north-eastern Swaziland, responsible for the depredations of the wildebeest. This indeed was repeatedly proposed in council.

The first real attempt at game preservation in Swaziland was made by the late David Forbes - who actively protected his game on his vast concession in north-eastern Swaziland. He was aided in his attempts at preservation by the harsh character of Forbes' Ranch, which, with its mosquitoes, high temperatures and lack of well distributed water, had successfully kept people at bay. It was also remote. After Forbes' death, a decline of this enormous wild animal nucleus set in and Swaziland's wildlife went effectively undefended for years thereafter.

About this time, His Majesty, King Sobhuza II, purchased Forbes' Ranch, to hold it in trust for the Swazi nation, and it thenceforth became known as Hlane. Both lawful and unlawful hunting went on unabated, in spite of the Game Laws.

Wildebeest remained vermin in Swaziland until we discovered that they were not protected by the Game Act, and had them returned to the Game Schedule in 1969. By this time the vast herds of former days had been reduced to mere remnants. 


\section{Thoughts on early migrations}

From these old records of wildlife movements in Swaziland, one thing stands out clearly - and that is the possibility that these so called invasions of wildebeest were nothing more than a seasonal migration pattern, which encompassed the enormous basin of bushveld boundered by the Lubombo range on the east, the Komati to the north, the Usutu to the south and by the mountainous country to the west. We see it as just one enormous cyclic migration such as is known to have happened in other places in past times, and much like the migrations that still occur to the north. That these invasions were unknown before the 1930's is easy to understand. Migrations are activated by a combination of factors one of which is pressure of population density. After the rinderpest the game was so depleted that all migratory stimuli were killed. Then, with the gradual recovery of the populations and their expansion into empty range, numbers were again reached in the early 1930 's which activated the migrations once more. Shortly before the 1930 's there is evidence to suggest that smaller more local movements took place. Before the rinderpest in 1896 there is virtually no written record, but by all other accounts Swaziland was "swarming with game".

Projecting the picture further back in time, and considering the encounters of the first pioneers with immense herds of wildebeest in the western high country, it conjures up something reminiscent of the great Serengeti - Mara migrations of East Africa. We suggest here the possibility of a periodic spillover of these wildebeest herds from this great bushveld basin, up against the Swazi escarpment and over into the highveld. This would obviously have been before significant Swazi settlement of the middleveld.

This migration theory is of course still conjecture, but there is much to support it. For instance the presence of ancient blue wildebeest remains from the Onink cave on the Swazi escarpment may contribute towards substantiating this. We are still researching the early presence and movement of wild animals across our borders.

\section{Injudicious mass exploitation of game}

Against a background of an over committed and skeleton police force - a background of largely unenforced Game Laws and the absence of a law enforcement body specifically designated to maintain them, and finally against a Colonial Government, indifferent to the African heritage - the slaughter of Swaziland's wildlife went virtually unchecked year after year. Extermination licences were easily obtainable by those who wished to be law abiding. Against these opportunities several enterprising ventures evolved. A piggery was started to take advantage of the vast protein resources freely available. This was apparently the sole justification for its coming into being. Game of all descriptions, including roan 
antelope, was boiled down and minced up and fed to the pigs. There was also the "Impala Express", a bus service, of relatively recent times (late 1940 's). Its claim to fame was that it exported about a thousand impala per week. At least one goods bus, and sometimes even two, left Bremersdorp (now Manzini) every day of the week except Sunday with its load of carcasses for the Johannesburg market. These buses were supplied by farmers and hunters alike, who delivered their bags to the Bremersdorp Road Motor Service station.

It is pertinent that most of those people responsible for the perpetration of many of these heinous activities were not only extremely wealthy people, but were also absentee owners of land in Swaziland.

Incredible as these stories may seem, there is ample evidence to back their authenticity. Many of the personalities involved in them are still alive today, though, in the current conservation climate, most of them are understandably reluctant to talk about it. Many of our older Swazis still clearly remember these atrocities against the Swazi wildlife heritage.

\section{Rapid decline of wild herds}

The pattern from the 1930's to the 1960's was one of development and of incredible exploitation. Inevitably the game, plentiful as it had been, steadily declined to remnant populations in some areas and totally disappeared from others. This in less than a lifetime.

Prince Makhungu, His Majesty's oldest surviving son who is leader of our delegation, himself witnessed time and again hordes of wildebeest, zebra and impala from elevated vantage points on the Lubombos and the Malindas. I myself recall as recently as 1950, travelling the length of Swaziland from Gollel to Border Gate, a distance of approximately 200 $\mathrm{km}$, and virtually never being out of sight of wildlife exceept on one or two isolated stretches of a mere few miles. On both sides of the road where one herd ended another began and this entire journey could be described to transect almost a continuous herd of mixed game. But by 1967, one could travel this road and not see a single wild mammal.

All the time the Colonial Government stood by, guiltless in its arrogance and totally indifferent to the vanishing African heritage. It was not theirs to lose. The Colonial Government watched while entire species were allowed to become extinct in the country. The roan antelope, formerly plentiful in eastern Swaziland, finally gave way when the last individual was found snared in 1961. The tsessebe probably finally succumbed in the late 1930's. Even the great herds on Hlane became depleted. With the settlement along the Umbuluzi river boundering Hlane to the north, the severing of this vast area by a railway line, and fencing to the south, east and west, what remained of the great herds found themselves at the mercy of the settlements. 


\section{Poaching}

Poaching had long since become established as the thing to do. To this day, little public stigma attaches to this offence in any sector of the community. To illustrate the extent the game laws were ignored in earlier years the story of a poacher who, having escaped unrecognised after shooting an oribi on the Mlilwane Sanctuary, returned the following day with the police and demanded his oribi back!

The Swazi, who had been denied the opportunity of having his appreciation for his wildlife heritage fulfilled, had understandably come to look upon wildlife as something to be taken at any price - if he didn't the foreigner would. It is often said in Swaziland that the Swazi is responsible for killing out the game. This is not true. It was the foreigner, under foreign rule, who was responsible for doing this. The Swazi certainly harvested the game as a resource, in the same way as had his ancestors done for centuries before him, but it was technological man who wiped out the great herds. Today's local poacher is merely a threat to the remnants of this formerly vast resource.

\section{Conservation efforts - proclamation of Mlilwane and Hlane Game Sanctuaries}

By 1960, approaches had been made to the Colonial Government to set aside some land where Swaziland's rapidly vanishing wild animals might find refuge and protection. Two areas were extensively investigated by Prof R H Compton and T E Reilly. Their suitability for wildlife and of displacing already established Swazi families from these areas was confirmed. Proposals for proclamation as protected wildlife areas were then submitted to the Colonial Government. These were turned down on the grounds that Transvaal's Kruger National Park and Natal's Hluhluwe Game Reserve could adequately service the people of Swaziland, and also that there were far more important social needs in the Protectorate. The local people were not even consulted on whether their wildlife heritage needed consideration in their own land.

These frustrations led to a private effort at conserving Swaziland's wildlife, which led to the establishment of the Mlilwane Game Sanctuary in 1961. The proclamation of the original 445 ha Mlilwane farm as a sanctuary attracted both support and opposition - at that stage mainly opposition. Apart from its eventual official proclamation, Mlilwane received no help or subsidy from the Colonial Government. Fearing for its continuity, and in order to perpetuate it, a properly constituted non-profit making Trust was created. Honorary Trustees were appointed and the Mlilwane farm was donated to this Trust in perpetuity for nature conservation purposes.

In the meantime, while Mlilwane was being established and stocked 
with animals from the vanishing wild populations of Swaziland including Hlane's, His Majesty became increasingly aware of the situation. It was then that His Majesty came to the rescue and, encouraged by the success of the Mlilwane effort, called for the protection of Hlane - the last refuge of Swaziland's dwindling wild herds. Hlane covers approximately 14200 ha of virgin lowveld, and comprises a high quality parklike Acacia nigrescens savannah. The greater portion of Hlane had in the past remained protected from settlement because it only annually, and very erratically, yielded surface stormwater stored temporarily in pans or natural depressions. Most of Hlane is naturally (like many other parts of the Swaziland bushveld) a wet season habitat. This limitation was the main reason for preserving the high quality savannah parklands which are so characteristic of Hlane today.

His Majesty placed the management of Hlane in the hands of T E Reilly, and its control in the hands of a committee which to this day remains answerable directly to himself. There were then approximately 200 wildebeest, 150 zebra and 600 impala. With limited funds and the honorary services of a few individuals, all effort at Hlane was initially focussed on anti-poaching for the first few years. Second priority was the re-establishment of species known to have existed there before. In 1967, Hlane was officially proclaimed a Game Sanctuary.

When Swaziland regained her independence from Britain in 1968, not a single protected area remained which had been established by Governmental promotion. It is true to say that nature conservation was very sadly neglected by the Colonial Government in Swaziland.

\section{Swaziland National Trust Commission}

Since independence we have the machinery in the form of the Swaziland National Trust Commission, to establish and maintain national parks in Swaziland. The Commission is a parastatal body under the Deputy Prime Minister's office. Its function is to establish and promote national parks, nature reserves, monuments, sacred places and the National Museum. The Commission came into being in 1972. Major Ian Grimwood, under the auspices of the LUCN, assisted in the legislation covering the Swaziland National Trust Commission Act, and recommended various areas as national parks and nature reserves. The Commission has followed some of these recommendations and purchased extensive tracts of land, though these areas have not yet actually been proclaimed as such. Hlane and Mlilwane together make up less than $1 \%$ of Swaziland's surface area, but it is the Commission's aim, in accordance with international recommendation, to bring at least $4 \%$ of the Kingdom under its protection.

Now that we are independent it is hoped that the conservation of our wildlife heritage and the preservation of our authentic African landscapes will be taken more seriously than has been the case in the past. 


\section{Conservation success}

Since the historical event in 1969 when Mlilwane was proclaimed, this sanctuary has grown ten-fold to 4450 ha in extent. Among its most cherished benefactors are Mrs B Wallis, who contributed the original farm, the SA Nature Foundation, the World Wildlife Fund, the National Parks Board of South Africa, the Natal Parks Board, Mr Ian Haggie, the Anglo American Corporation, Leyland Motor Corporation of South Africa, Total (South Africa) (Pty) Ltd., the Swaziland National Trust Commission, all Patrons of Mlilwane, who donated at least R1 000 each for capital development. Mlilwane's honorary Trustees have selflessly devoted time and experience to the welfare of the Sanctuary, and - most important of all - Mlilwane's Chief Patron, His Majesty King Sobhuza II, did likewise, without whose support Mlilwane could not have expanded or even survived. Many other benefactors, too numerous to mention here, have also contributed generously to the establishment and success of this sanctuary.

Mlilwane has been singularly successful and has by its own merits attained full economic viability on its recurrent account, without being blatantly commercialized. However, Mlilwane does now suffer frustrations in lack of capital which is preventing the fencing, and therefore, control, of its northern extension. This property constitutes half of the area of the Sanctuary, and the only currently protected highveld in the country. Funding is also required for a vitally important and urgent nation wide environmental education programme which is being undertaken. This programme is aimed at all sectors of the population, mainly through mass media and the formal education system.

So far Hlane also has a record of success. Today, nine years after protection was applied to Hlane, enormous surpluses of wildebeest and impala have resulted, these species having increased to 4500 and 6000 respectively from the former remnants. Zebra have also responded well and now number in excess of six hundred. Kudu, waterbuck and bushbuck somehow found their way back into protection from persecuted lands. Steenbok and warthog have also increased and today Hlane has a reasonably safe distribution of these species. White rhino, nyala, ostrich and giraffe have been introduced and are now well established.

\section{New threats}

Today, as Hlane is finding its feet, it faces new economic pressures coal, sugar, diamonds and domestic stock. The battle for Hlane is by no means won. In fact it has only just begun. It is unlikely in the long term, without a shift in values, that Hlane can survive all these pressures. If it does not, Swaziland will have lost a treasure yet unrealized, materially unevaluated and appreciated only by a very few.

In the face of these threats, it soon became obvious that no economic 
argument we could raise could possibly withstand the overwhelming pressures of development. There is no way Hlane can be justified on short-term economic grounds against millions of Rand worth of development and material opportunity. One of these developments, now estimated at costing R120 million, promises vast employment possibilities and enormous revenue prospects.

There remained only one last remote chance to save Hlane. As slim as it appeared to be at the time, it was the only course open to us, and it has helped to hold the situation from total collapse since 1972. It was then that we began by lobbying for recognition of traditional-, cultural-, aesthetic-truly African values. This was followed by the sectioning and dating of a tree from the Hlane Sanctuary. The tree was an old dead leadwood Combretum inberbe. We had a hunch that it would be old, but it turned out to be older than we had dared to hope. The South African CSIR dated it by the C14 method, as being approximately 1050 years. The margin of error given was \pm 37 years. More significantly, this tree died in 1823, long before White man had come to Swaziland. It was still well preserved and solid, having withstood fire year after year in a fire climax savannah woodland. With this information we carefully prepared and presented a case for the survival of Hlane to His Majesty, King Sobhuza II.

We are presently engaged with a much larger survey of Hlane's arboreal vegetation, in an effort to determine its age structure. The results will undoubtedly be useful not only for consolidating and fortifying the case for Hlane and other wild places in Swaziland, but we see them also as a basis for further scientific research which may unfold to us many aspects yet unknown in nature.

The ancient ecosystem of which Hlane is part, could in the future be destined to destruction at the stroke of a pen, as has already happened to the greater part of this system. Alternatively, this ancient ecosystem could be protected and form the basis of a sustained supply of protein for the nation, traditional hunting opportunities, increasingly important environmental education and of recreational fulfilment. The choice we make depends on our values. We can only hope that this choice will not be a short-term economic one.

It is indeed fortunate for conservation in Swaziland that His majesty is one who has sophisticated values which temper the shallower short-term values of much of the developed world.

Hlane and our other wild areas will undoubtedly come under increasing pressures in the years ahead. In fact we have no hesitation predicting that Africa will ultimately lose her wild places in favour of total, and often only temporarily beneficial, development - unless a massive change of heart comes about in time and an adjustment in values occurs to accord Africa's natural heritage the priority it deserves.

The price for total acceptance of foreign values, which the Swazi is increasingly being persuaded to adopt, must inevitably be a loss of 
identity. Africa is steadily losing her identity. Most of Africa in recent history has been colonized by one or other foreign power. These Colonialists have influenced and modified African culture, tradition, and the continent as a whole.

With the colonizing people came values alien to Africa - values very often which, when imposed upon the local African landscape, struck discord with their surroundings. "Improved" or "tamed" are terms often used to describe this modification. At old Colonial establishments, what immediately becomes noticeable is the change in vegetation composition. Suddenly, in an African setting, one finds jacarandas, gums, poinsettias and cannas and a host of other foreign plants. One finds that these plants have usually replaced the rich local flavour of Acacia, Combretum or even Podocarpus species, which have been hacked down in favour of them. We have been so conditioned by foreign values that we now find ourselves not only accepting them, but actually promoting them - and discarding our own. Today, these foreign values have become so much a part of our country that many Swazis do not even know, for instance, that gum trees are foreign. Many Swazi children have never seen an impala - our most common larger mammal.

This trend happily is changing in some places, though its influence has become an essential and lasting characteristic of many African landscapes. There is hardly a place left in Swaziland today where one can stand, look about, and see a purely African scene.

One of the salient causes for the disappearance of authentic Africa today is the influence exerted upon the local scene by foreign experts. Being a developing continent, Africa is the focus of great numbers of foreign experts. These experts are as varied as the countries they come from. The only thing they have in common is that none of them really understand the local situation, and they do not speak the local language. Most of these foreign experts have no idea of local values, seldom accept or even understand that there may be values other than their own, and so they impose upon our local scene their own foreign thinking, in total disregard for ours. Comparatively few of these experts take cognisance of local feelings.

Exchange of ideas is healthy and offers great benefits. There is a misconceived idea that experts must come from far away - hence the appropriate definition of an expert - "a wise guy a long way from home". Many of these so called experts are never in one place long enough to see the results of their work and can therefore never draw from the experience of their own endeavours. Some of them cannot find employment in their own countries, and so somehow get themselves set up as experts and travel the undeveloped world as imposters at someone else's expense. Many find Africa an exciting laboratory and develop their knowledge and experience at local cost. 


\section{Environmental insensitivity}

Environmentally speaking, the educational deficiency sometimes encountered among professional people is frightening. Engineers, architects and economists particularly are notoriously insensitive to the natural qualities of the African environment, and in the name of progress still insist on scarring the land unnecessarily. Many of them apply their projects at all costs, with little or no regard for local values. Their work often unnecessarily clashes with nature's way, and is largely responsible for the disappearance of authentic Africa.

One of the tragedies of Africa is that her developers are still at war with nature. The result is that we in Africa, having imported some technology, and having it all available to us in countless forms, have not yet developed the environmental sensitivity necessary to handle it responsibly. To allow a bulldozer in the control of environmentally insensitive developers is not only irresponsible - it is tantamount to vandalism. Unnecessary destruction caused in this way is something we may live to regret, and certainly our children with every justification, will grow up to condemn. We must remember that these mistakes have all been made before. Environmentalists repeatedly warn us against them, yet we persist in repeating them.

Africa is losing her identity largely through the imposition of foreign economic values. Economists often believe they are justified in insisting on economic criteria being the single determinant governing their modification of authentic Africa. We in Africa are being successfully persuaded that there is nothing that money cannot buy. Our insistence at weighing up development solely in terms of economics and casting aside all other values, is leading not only to the destruction of the last of Swaziland's wild places, but also the the destruction of the rural Swazi. One of the immediate and irreversible results of transforming vast areas of remaining Africa into factory orientated production units is the displacement of the rural African and his flocks. Consequently, the imposition upon him of an urban situation to which he is naturally maladjusted and a system which often is unable to absorb him, creates disillusionment and frustration. His whole way of life is destroyed and this inevitably results in social problems which in the final analyses may even outweigh the advantages to the community of the development in question. It is surely time now to pause and to take stock. The long term cost of all future developments must be appraised from all viewpoints in addition to the economic viewpoint. We would do well to be wary of being persuaded in favour of economics - particularly short term economics - as a single criterium.

Another tragedy which has befallen Africa is that this continent has become the "dumping ground" for the developed world. The African market is wide open to commodities which have been tried and rejected by the more developed countries. 
Good examples of this deceit may be seen in the continued use in Africa of pesticides which have been banned after long use in overseas countries for the dangers they have now been found to present, and the harm which they do. Another example lies in the pornographic films which are shown here.

Meaningful exposure of our people to the authentic natural values of our continent is long overdue. Pride in the irreplaceable African heritage must be developed, and to protect it from further harmful exploitation, its importance must be placed in its rightful context.

\section{African aesthetics - a political cause}

Swaziland is a particularly small country, and the impact of development on it is therefore more meaningful than it is at the moment in most of the larger countries of Africa. Being so small, and with its compounding human population, Swaziland's open spaces are under terrific pressure. More so than most other countries, Swaziland will be hard pressed to retain representative samples of her undeveloped areas, including parks, and she will certainly increasingly be called upon to justify them.

This has not been a scientific paper, because science alone is not going to save Africa's wild places. Neither does it acknowledge the validity of economics being promoted as the salient factor of justification for our wild areas, because economics usually end up contesting the retention of these areas. Only politics can save our wild places, so this paper must end on a strong political tone.

How often has it been said that politics should be kept out of conservation? To hold with this sentiment is to be unrealistic. Conservation is one of the most political issues of the moment on this continent. This is so because it involves land, and land is what politics and conservation are all about. They are inseparable. Conservation is in the beginning and in the end a political decision.

Economics can be said to be the process by which financial independence, or at least financial viability, is gained. Economics are therefore very important. Conservation is increasingly expected to make economic sense, and we are always at pains to justify our wild places on economic grounds. Yet is is ridiculous to suggest that our wild areas should have to be economically justified, when we haven't even learnt to acknowledge nature. We in Africa, having been influenced by values arising from Man's imposed dominance over nature's bounty, and having inherited such vast natural resources at no cost, tend to take nature for granted. We pay extravagantly for alcohol or for an evening meal; but we usually resist paying equitably for access to wild areas. We still remunerate the custodians of our wild places on the basis that they perform a labour of love and dedication, instead of according to their true worth. And yet, with this attitude, we still expect nature to stand up against economics. 
We're losing ground. Here and there maybe we win a little battle, but then somewhere else we lose a much larger battle - one of more significance to conservation as a whole and in the final analysis our strategy is one of defence and retreat. This is because conservationists, instead of politicians, are defending or promoting our case.

However, if it is demonstrated that the conservation of nature is indeed the conservation of Africa's heritage and identity - and that this is a nationalistically defenceworthy cause - if we could touch the hearts of the people and arouse their pride in our heritage and identity, and their indignation at the loss of it - then we may reverse the trend. Much has been said about the futility of bandying the concept of aesthetics and that hungry people cannot be concerned about such things. We do not entirely go along with this philosophy.

There are certain things in life that we do not sell for money - things that money simply cannot buy. Our heritage, alongside our identity and our African aesthetics, merits recognition as examples.

\section{Strategy for survival}

Practically speaking, we see three ways in which the survival of the African heritage can be made possible in Swaziland in the long term:

(i) Politically, where the decision-makers enforce its survival;

(ii) Educationally, where education may become the instrument of political influence, and,

(iii) By the participation of the nation as a whole in the proceeds of conservation (meat, hunting, skins, etc.). Here our conservation areas must not only be said to be beneficial - they must be tasted to be. An annual or periodic harvest must be made available both individually to the top decision-makers, and collectively to local people - particularly those who bear the brunt of the conservation exercise. We refer here to those people whose fields are raided by animals, who have been displaced by decree to make room for wildlife, who see grass eaten by game instead of by their cattle, and who generally for one reason or another harbour resentment against nature conservation and all it stands for.

Of these three ways, the first is most important. The second and third merely facilitate the first. The first two must be influenced by overtones of nationalistic pride. Economic and scientific considerations are obviously also important and should always be infused into the conservation argument as contributing support.

The success of conservation in the long term ultimately depends on the control of human population growth - this being the root cause of many problems facing us today. The predicted implications of this problem are staggering, and if the availability of food does not serve as a 
limiting factor to forestall these predicitions, we are certainly headed for catastrophe. This concept must therefore be written into all environmental education programmes.

So much is already lost - so little is left. Time is passing, and pressures on our wild areas are relentlessly increasing. The only chance we have left is to condition our youth, and to persuade the political decisionmakers to take up our cause. Decisions on the survival of Mlilwane and Hlane, for instance, will be made at Lobamba. In fact, the fates of these sanctuaries may even be decided by people who have never visited them.

It is understandably very difficult, particularly for developing countries to resist the promised wealth and benefits of development, whether or not they are short-term. The bigger the proverbial carrot that is hung before them, the more attractive it is and the more difficult to resist. If our heritage and our identity are to be spared being sold for riches, then the motivation to preserve them must transcend material values.

We believe that, if anything politics and not economics, will be the overriding factor in tipping the scales in favour of our cause.

We appreciate that it is easy to speak from the vantage point of a full stomach and a sheltered sky. But nevertheless, individuals and nations have often willingly borne the stresses of want and hardship, and have doggedly forgone the attractions of comfort and necessity for a cause. When the dawn breaks, if it ever does, to reveal that a nation's identity is wrapped up in its heritage - including the authenticity of its territorial landscapes - then and then only may the conservation case stand against the case for material values. Until that day dawns our wild places will continue to vanish. 